\title{
Effects of ethanol and phenobarbital treatments on the pharmacokinetics of toluene in rats
}

\author{
Rui-Sheng Wang, Tamie Nakajima
}

\begin{abstract}
Rats were exposed to toluene at a wide range of concentrations from 50 to $4000 \mathrm{ppm}$ for six hours, and the effects of ethanol and phenobarbital (PB) treatments on the pharmacokinetics of toluene metabolism were investigated. Ethanol treatment influenced toluene metabolism mainly at low exposure concentrations. Thus ethanol accelerated the clearance of toluene from blood only when the blood concentration of toluene was not high $(<360 \mu \mathrm{M})$, and ethanol increased hippuric acid (HA) excretion in urine more significantly at low ( $<250 \mathrm{ppm}$ ) than at high atmospheric toluene concentrations. Ethanol also expressed a similar effect on $p$-cresol excretion as on HA, but had little effect on o-cresol. Phenobarbital treatment promoted the urinary excretion of all of the metabolites of toluene, especially after exposure to high toluene concentration. As well as HA, benzoylglucuronide (BG) and free benzoic acid were found in urine. These are the products of the side chain metabolism of toluene. Amounts of BG could be detected when the urinary excretion of free benzoic acid exceeded $5 \mu \mathrm{mol} / \mathrm{kg} / 6 \mathrm{~h}$, indicating that a great deal of benzoic acid is required for the formation of BG. The Michaelis constant $\left(K_{m}\right)$ and the maximum rate of metabolic excretion in urine during six hours exposure $\left(V_{\max }\right)$ of isozymes involved in the excretion of toluene metabolites were calculated, and correlated with the subtypes of cytochrome P-450. The significance of the result was suggested in the biological monitoring of exposure to toluene.
\end{abstract}

Toluene has attracted great attention in recent years because of its wide use as a solvent, synthetic material, and component of gasoline, and its toxic potential on the central nervous system, liver, and kidney. ${ }^{1-3}$

Department of Hygiene, Shinshu University School of Medicine, Matsumoto 390, Japan R-S Wang, T Nakajima
We reported previously, from in vitro studies, ${ }^{4}$ that toluene is mainly metabolised at its side chain to benzyl alcohol, and at least three isozymes of cytochrome $\mathbf{P}-450$ are involved in the formation of the metabolite; the low $(0 \cdot 13-0 \cdot 17 \mathrm{mM})$ and high $(0 \cdot 60-$ $0.87 \mathrm{mM}) \mathrm{K}_{\mathrm{m}}$ isozymes are found in naive rat liver microsomes, with the low $K_{m}$ being ethanol inducible; another is an isozyme $(0.90 \mathrm{mM})$ inducible by phenobarbital (PB), but absent in naive rats. Metabolites from hydroxylation at ring positionsnamely, $o$ - and $p$-cresol-share less than $1.5 \%$ and $2.8 \%$ respectively of total metabolites in rat liver microsomes; the high $\mathrm{K}_{\mathrm{m}}$ and low $\mathrm{V}_{\max }$ values of isozymes responsible for aromatic hydroxylation may account for the result. The low and high $\mathrm{K}_{\mathrm{m}}$ isozymes for benzyl alcohol and $p$-cresol are cytochrome P-450IIE1 and P-450IIC11 respectively; the $\mathrm{PB}$ inducible isozyme for the formation of the three metabolites is cytochrome P-450IIB. ${ }^{5}$

In our present study, we investigated the in vivo metabolic pattern of toluene in rats, especially the pattern of urinary excretion of toluene metabolites, at seven exposure concentrations ranging between 50 and $4000 \mathrm{ppm}$. The effect of ethanol and PB treatments on toluene pharmacokinetics was also studied in that these two chemicals induce different types of cytochrome P-450 that are known to be involved in toluene metabolism in vitro. ${ }^{45}$

\section{Materials and methods}

ANIMALS AND TREATMENTS

Male Wistar rats (Nippon SLC Inc, Shizuoka, Japan) were housed individually in stainless steel cages at a constant temperature $\left(20(\mathrm{SD} 2)^{\circ} \mathrm{C}\right)$ with a 12 hour light dark cycle. Food (Clea CE-2, Nippon Clea, Tokyo) and water were available ad libitum. Rats were acclimatised for two weeks, and at the age of 8 weeks, they were divided into three groups: control, PB, and ethanol groups. The first two groups were fed a nutritionally adequate liquid diet (basal diet) described by DeCarli and Lieber ${ }^{6}$ and slightly modified. ${ }^{7}$ The third group was fed an isocaloric ethanol diet $(2 \mathrm{~g}$ ethanol $/ 80 \mathrm{ml})$ in which sucrose content was partially replaced with ethanol and corn oil. The animals were supplied daily with $80 \mathrm{ml}$ $(1 \mathrm{kcal} / \mathrm{ml}$ ) liquid diets per rat at $4.00 \mathrm{pm}$ as their only 
source of nutrition for three weeks. Rats in the PB group were administered $P B$ at $80 \mathrm{mg} / \mathrm{kg} /$ day intraperitoneally at $\mathbf{1 0 . 0 0}$ am for four days before exposure to toluene.

\section{TOLUENE EXPOSURE}

Toluene inhalation was conducted in a dynamic flow system as described previously. ${ }^{8}$ Rats were exposed for six hours to toluene vapour at concentrations of 0 , $50,100,250,500,1000,2000$, and $4000 \mathrm{ppm}$ from 10.00 am to $4.00 \mathrm{pm}$. Toluene concentration in the exposure chamber was monitored every 15 minutes by a gas chromatograph equipped with a hydrogen flame ionisation detector. The variation of toluene concentration remained within $10 \%$ of the required value during the six hour exposure. Rats in the $0 \mathrm{ppm}$ group were exposed to solvent free room air in the same chamber. Animals were removed to metabolic cages individually and supplied only with water after each exposure session.

\section{TOLUENE CONCENTRATION IN BLOOD}

Blood samples were taken from the tail at 0 , one, two, four, and six hours after exposure, and the concentration of toluene in blood was measured by a syringe equilibration method. ${ }^{9}$

MEASUREMENT OF URINARY METABOLITES OF TOLUENE Urine samples were collected from each rat during the six hour exposure and at four, eight, 12, and 18 hours after termination of each exposure. Hippuric acid concentration was determined by the method of Takeuchi et $a l^{10}$ with slight modifications in the concentration of acetonitrile, acetic acid, and $\beta$ cyclodextrin of the mobile phase, and with the substitution of Unisil C18 for Senshupack ODS as the column packing.

For HA and free benzoic acid (F-BA) measurements, urine samples were centrifuged at $3000 \mathrm{rpm}$ for 15 minutes. After diluting the supernatant with water, $10 \mu \mathrm{l}$ of the solution was injected into a high performance liquid chromatograph (HPLC, Hitachi L-6000) with a UV-Vis detector (Hitachi L-4200) and a chromato-integrator (Hitachi E-2500). The analytical conditions were: column, $4.0 \phi \times 250 \mathrm{~mm}$ stainless steel column packed with Unisil C18 (Gasukurokogyo Inc, Tokyo); mobile phase, $25 \%$ acetonitrile water solution containing $0.5 \% \beta$-cyclodextrin and $0.5 \%$ acetic acid at a flow speed of $0.8 \mathrm{ml} / \mathrm{min}$; wave length, $228 \mathrm{~nm}$. Under these conditions the detection limit was found to be $11.5 \mu \mathrm{g} / 1$ for HA and $17.6 \mu \mathrm{g} / 1$ for F-BA.

Another metabolite was found in urine samples of rats exposed to high concentrations of toluene; this peaked just before the HA peak on the chromatogram, and showed a peak height toluene dose relation. To clarify the unidentified peak, we added $500 \mathrm{IU} \beta$-glucuronidase to $1 \mathrm{ml}$ of the urine samples and found that the peak before HA was completely eliminated from the urine and the peak height of benzoic acid increased correspondingly after incubation for 30 minutes at $37^{\circ} \mathrm{C}$. The peak height of HA was not influenced by the treatment. This suggests that the unidentified peak represented benzoylglucuronide (BG), a conjugate of benzoic acid with glucuronic acid. From the difference in the amount of F-BA between intact urine and enzyme treated urine, the amount of BG was calculated.

For $o$ - and $p$-cresol measurement, urine samples were hydrolysed by adding $0.5 \mathrm{ml} 15 \% \mathrm{HCl}$ to $1 \mathrm{ml}$ of urine sample in a tube with cap. The mixture was then heated at $100^{\circ} \mathrm{C}$ for 60 minutes. The samples were centrifuged at $3000 \mathrm{rpm}$ for 15 minutes, and after diluting the supernatant with water, $10 \mu \mathrm{l}$ was injected into the HPLC apparatus, with the analytical conditions: column, $4.0 \phi \times 250 \mathrm{~mm}$ stainless steel packed with Unisil C18; mobile phase, $25 \%$ acetonitrile solution at a flow speed of $1.2 \mathrm{ml} /$ min; wave length, $200 \mathrm{~nm}$. The detection limits of this method for $o$ - and $p$-cresol were 5.2 and $5.0 \mu \mathrm{g} / 1$ respectively.

\section{STATISTICS}

Statistical significance was determined by the Student's $t$ test if the variances of data were not uniform, otherwise by Duncan's new multiple range test. The criterion for significance was set at $\mathrm{p}<0.05$.

\section{Results}

TOLUENE CONCENTRATION IN BLOOD

Figure 1 shows the blood concentrations of toluene at

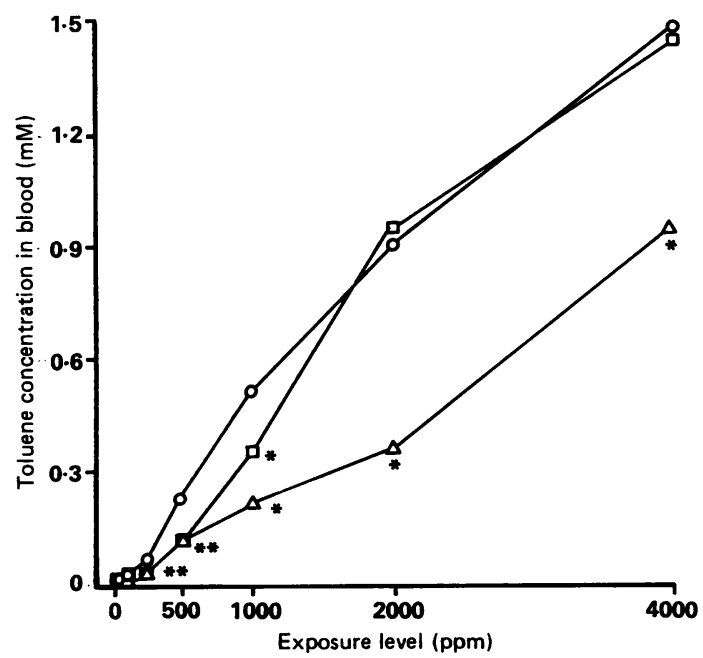

Figure 1 Toluene concentration in rat blood at the end of six hour exposures to different concentrations of toluene. $O$, control group; $\square$, ethanol group; $\triangle, P B$ treatment group. Each symbol represents the mean determined from five rats. ${ }^{\star} p<0.05$ (significantly different from control group). 



Figure 2 Decay curves of toluene in blood after six hour exposures to different concentrations of toluene. $\bigcirc$, control group; $\square$, ethanol group; $\triangle, P B$ treatment group. Each symbol represents the mean from five rats. ${ }^{\text {Significantly different from control }}$ group $(p<0.05)$. 

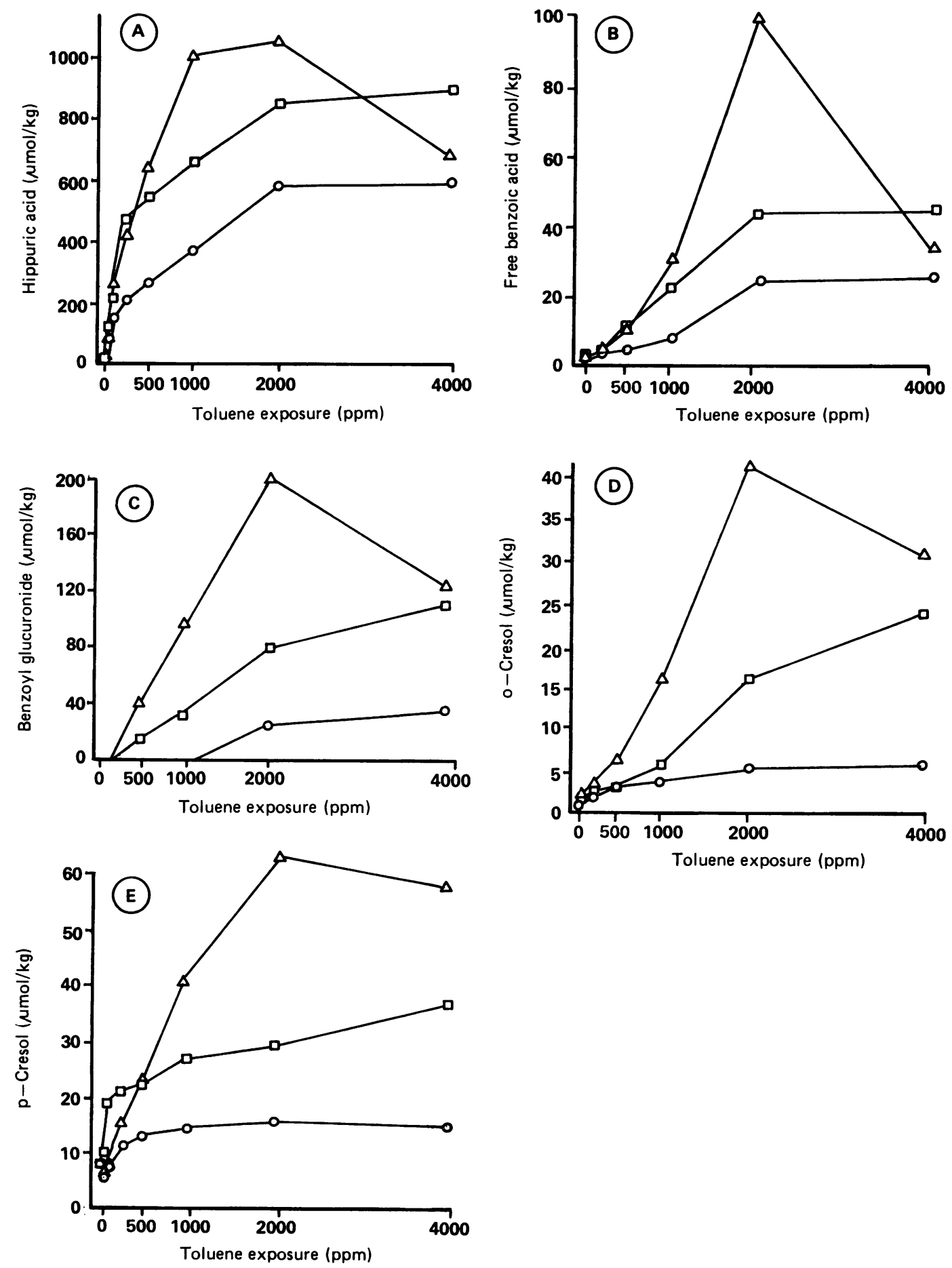

Figure 3 Excretion of toluene metabolites in urine of rats during six hour exposures to different concentrations of toluene. $\bigcirc$, control group; $\square$, ethanol group; $\triangle, P B$ group. Each point represents the mean from five rats. $A, H i p p u r i c$ acid; $B$, free benzoic acid; $C$, benzoyl glucuronide; $D, o$-cresol; $E, p$-cresol. 
the end of six hours of exposure to different concentrations of toluene. At low exposure concentrations (50,100, and $250 \mathrm{ppm})$, the blood concentration increased slowly with increasing inhalation concentration in control rats, and then rapidly when the exposure concentration was over $250 \mathrm{ppm}$. In ethanol treated rats, the blood concentration of toluene was close to that of control rats at 50 and $100 \mathrm{ppm}$ toluene exposures, but the value was significantly lower at 250,500, and $1000 \mathrm{ppm}$ inhalations than in the control group, indicating that treatment with ethanol accelerates the clearance of toluene from blood. At high exposures (2000 and $4000 \mathrm{ppm}$ ) differences in blood concentrations of toluene between ethanol and control groups became insignificant. The blood $v$ exposure concentration curve of PB treated rats had a more shallow slope compared with the ethanol group, indicating that PB treatment increased toluene metabolism more than ethanol treatment. This effect was more significant at high exposure concentrations (2000 and $4000 \mathrm{ppm}$ ).

On the other hand, blood concentration of toluene decreased exponentially with time after stopping exposure in the three groups (fig 2). At 250-1000 ppm exposures, ethanol treatment decreased toluene concentration in blood significantly at all five time points. At the two highest exposures the difference became significant only when the blood concentration decreased below $360 \mu \mathrm{M}$-that is, two hours after $2000 \mathrm{ppm}$ and six hours after exposure to $4000 \mathrm{ppm}$. This suggests that the effect of ethanol is limited to lower substrate concentrations. Blood concentrations of toluene in PB treated rats, from 250-4000 ppm exposures, were significantly lower than those of control rats at any sampling time.

\section{EXCRETION OF TOLUENE METABOLITES IN URINE}

\section{Hippuric acid}

Figure 3 shows the excretion patterns of five metabolites (HA, F-BA, BG, $o$-, and $p$-cresol) in urine during six hours of exposure to different toluene concentrations. As shown in fig 3A, the amount of HA in urine increased rapidly at low exposure concentrations $(50-250 \mathrm{ppm})$ and then slowly with increasing toluene concentrations. It reached a maximum after exposure to $2000 \mathrm{ppm}$ toluene. In ethanol treated rats, the excretion pattern was similar to that of controls, but the excreted amount was much larger, especially at low toluene concentrations (50-250 ppm). Excretion of HA increased almost linearly up to $1000 \mathrm{ppm}$ toluene in PB treated rats. At high toluene concentrations, especially at $4000 \mathrm{ppm}$ exposure, PB treated rats looked weak and walked unsteadily even during exposure. The volume of urine excreted in the first four hours after stopping exposure in the $\mathrm{PB}$ group was more than twice that in the control or in the ethanol group, and was thereafter decreasing. Of five animals, three rats died within 12 hours of stopping $4000 \mathrm{ppm}$ exposure. The decrease in the excretion of HA and other urinary metabolites may be caused by heavy intoxication.

HA excretion decreased with time (data not shown), and almost to the level of non-exposed rats 18 hours after stopping exposure to 50 and $100 \mathrm{ppm}$. At 2000 and $4000 \mathrm{ppm}$ exposures, urinary HA concentration did not decrease even after stopping exposure, indicating the vast accumulation of toluene in adipose tissue and other organs.

\section{Free benzoic acid}

Free benzoic acid was detected even in non-exposed rats. Ethanol treatment significantly increased the urinary excretion of F-BA when toluene exposure exceeded $100 \mathrm{ppm}$. Phenobarbital had a more moderate effect (fig 3B).

\section{Benzoylglucuronide}

Benzoylglucuronide was firstly detected at 2000,500 , and $500 \mathrm{ppm}$ exposure in control, ethanol, and $\mathrm{PB}$ groups respectively, when F-BA excretion in urine was above $5 \mu \mathrm{mol} / \mathrm{kg}$, and $\mathrm{HA}$ excretion was above $500 \mu \mathrm{mol} / \mathrm{kg}$. Both ethanol and PB increased BG excretion significantly (fig $3 \mathrm{C}$ ).

\section{$o$-Cresol}

$o$-Cresol was detected only in urine of toluene exposed rats. It increased with toluene exposure up to $1000 \mathrm{ppm}$ exposure (fig 3D). Ethanol increased $o$ cresol excretion only at high toluene exposures $(1000$, 2000 , and $4000 \mathrm{ppm}$ ), whereas PB showed this effect from $50 \mathrm{ppm}$.

\section{p-Cresol}

$p$-Cresol was detected even in non-exposed rats. In the control group, urinary $p$-cresol increased with increasing toluene concentration up to $1000 \mathrm{ppm}$ exposure (fig 3E). Ethanol treatment significantly increased $p$-cresol excretion from $100 \mathrm{ppm}$ exposure and PB promoted excretion from 250 to $2000 \mathrm{ppm}$ toluene exposure.

\section{Total metabolism}

Table 1 lists the cumulative amounts of five metabolites of toluene in $\mathbf{2 4}$ hours after the start of six hours of exposure to different concentrations of toluene. Hippuric acid made up $90-93 \%$ of all metabolites at exposure concentrations of $100-2000$ $\mathrm{ppm}$. At exposure to $4000 \mathrm{ppm}$, it decreased to $84 \%$ because of the large formation of $B G$, but was still the main metabolite. The percentage of $o$-cresol varied between 0.5 and $1.1 \%$ without any distinct tendency, whereas the percentage of $p$-cresol decreased gradually with increase in exposure. The real amount of $p$-cresol excretion did not obviously increase until exposure to $250 \mathrm{ppm}$ toluene; above this level it increased with toluene concentration. 
Table 1 Cumulative amount of urinary metabolites in 24 hours during and after a six hour exposure to different concentrations of toluene

\begin{tabular}{|c|c|c|c|c|c|c|}
\hline Toluene (ppm) & Total & $H A$ & $F-B A$ & $B G$ & o-Cresol & p-Cresol \\
\hline \multicolumn{7}{|c|}{ Control group } \\
\hline 0 & $\begin{array}{l}40.9 \\
(100)\end{array}$ & $\begin{array}{l}12 \cdot 7(2 \cdot 9) \\
(31 \cdot 1)\end{array}$ & $\begin{array}{l}2 \cdot 4(1 \cdot 2) \\
(5 \cdot 9)\end{array}$ & ND & ND & $\begin{array}{l}25.8(10.8) \\
(63.0)\end{array}$ \\
\hline 50 & $\begin{array}{l}175 \cdot 9 \\
(100)\end{array}$ & $\begin{array}{l}146 \cdot 3(11 \cdot 7) \\
(83 \cdot 2)\end{array}$ & $\begin{array}{l}3.7(1 \cdot 4) \\
(2 \cdot 1)\end{array}$ & ND & $\begin{array}{l}0.9(0 \cdot 1) \\
(0.5)\end{array}$ & $\begin{array}{l}25 \cdot 0(2 \cdot 0) \\
(14 \cdot 2)\end{array}$ \\
\hline 100 & $\begin{array}{l}348 \cdot 5 \\
(100)\end{array}$ & $\begin{array}{l}315 \cdot 8(62 \cdot 5) \\
(90 \cdot 6)\end{array}$ & $\begin{array}{l}5.1(4 \cdot 0) \\
(1.5)\end{array}$ & ND & $\begin{array}{l}1.7(0.3) \\
(0.5)\end{array}$ & $\begin{array}{l}26.0(3.5) \\
(7.5)\end{array}$ \\
\hline 250 & $\begin{array}{l}594 \cdot 1 \\
(100)\end{array}$ & $\begin{array}{l}545.6(38.4) \\
(91.8)\end{array}$ & $\begin{array}{l}5.6(2.4) \\
(0.9)\end{array}$ & ND & $\begin{array}{l}4.5(0.9) \\
(0.8)\end{array}$ & $38 \cdot 4(6 \cdot 7)$ \\
\hline 500 & $\begin{array}{l}858 \cdot 7 \\
(100)\end{array}$ & $\begin{array}{l}802 \cdot 3(126 \cdot 8) \\
(93 \cdot 4)\end{array}$ & $\begin{array}{l}7.5(2 \cdot 7) \\
(0.9)\end{array}$ & ND & $\begin{array}{l}5.8(2 \cdot 1) \\
(0.7)\end{array}$ & $43 \cdot 1(5 \cdot 7)$ \\
\hline 1000 & $\begin{array}{l}1221 \cdot 7 \\
(100)\end{array}$ & $\begin{array}{c}1136 \cdot 0(94 \cdot 6) \\
(93 \cdot 0)\end{array}$ & $\begin{array}{l}19 \cdot 7(4 \cdot 0) \\
(1 \cdot 6)\end{array}$ & ND & $\begin{array}{l}12.5(0.9) \\
(1.0)\end{array}$ & $\begin{array}{l}53.5(12 \cdot 7) \\
(4 \cdot 4)\end{array}$ \\
\hline 2000 & $\begin{array}{l}3121 \cdot 1 \\
(100)\end{array}$ & $\begin{array}{c}2869 \cdot 7(252 \cdot 2) \\
(91.9)\end{array}$ & $\begin{array}{l}61 \cdot 7(14 \cdot 3) \\
(2 \cdot 0)\end{array}$ & $\begin{array}{l}86 \cdot 0(6 \cdot 0) \\
(2 \cdot 8)\end{array}$ & $\begin{array}{l}25 \cdot 8(9 \cdot 4) \\
(0 \cdot 8)\end{array}$ & $\begin{array}{l}77.9(5.8) \\
(2.5)\end{array}$ \\
\hline 4000 & $\begin{array}{l}4050 \cdot 9 \\
(100)\end{array}$ & $\begin{array}{l}3407 \cdot 1(504 \cdot 1) \\
(84 \cdot 1)\end{array}$ & $\begin{array}{l}122 \cdot 3(59 \cdot 5) \\
(3.0)\end{array}$ & $\begin{array}{l}351 \cdot 5(32 \cdot 9) \\
(8 \cdot 7)\end{array}$ & $\begin{array}{l}45 \cdot 6(6 \cdot 7) \\
(1 \cdot 1)\end{array}$ & $\begin{array}{l}124 \cdot 4(13 \cdot 8) \\
(3 \cdot 1)\end{array}$ \\
\hline \multicolumn{7}{|c|}{ Ethanol group } \\
\hline 0 & $\begin{array}{c}61 \cdot 0 \\
(100)\end{array}$ & $\begin{array}{l}18 \cdot 3(4 \cdot 2)^{\star} \\
(30 \cdot 1)\end{array}$ & $\begin{array}{l}0.9(0.1) \\
(1.4)\end{array}$ & ND & ND & $\begin{array}{l}41 \cdot 8(7 \cdot 0)^{\star} \\
(68 \cdot 5)\end{array}$ \\
\hline 50 & $\begin{array}{l}249 \cdot 3 \\
(100)\end{array}$ & $\begin{array}{l}202 \cdot 3(46 \cdot 9)^{\star} \\
(81 \cdot 1)\end{array}$ & $\begin{array}{l}3.5(1.4) \\
(1.4)\end{array}$ & ND & $\begin{array}{l}1 \cdot 4(0 \cdot 1)^{\star} \\
(0 \cdot 6)\end{array}$ & $\begin{array}{l}42 \cdot 1(11 \cdot 2)^{\star} \\
(16.9)\end{array}$ \\
\hline 100 & $\begin{array}{l}436.9 \\
(100)\end{array}$ & $\begin{array}{l}379.5(14.5) \\
(86.9)\end{array}$ & $\begin{array}{l}3.9(1.7) \\
(0.9)\end{array}$ & ND & $\begin{array}{l}2.0(0.5) \\
(0.5)\end{array}$ & $\begin{array}{l}51.5(3.9)^{\star} \\
(11.8)\end{array}$ \\
\hline 250 & $\begin{array}{l}804 \cdot 0 \\
(100)\end{array}$ & $\begin{array}{l}738 \cdot 7(111 \cdot 1)^{\star} \\
(91 \cdot 9)\end{array}$ & $\begin{array}{l}6.9(0.7) \\
(0.9)\end{array}$ & ND & $\begin{array}{l}3.8(0.5) \\
(0.5)\end{array}$ & $\begin{array}{l}54 \cdot 6(10 \cdot 3) \star \\
(6 \cdot 8)\end{array}$ \\
\hline 500 & $\begin{array}{l}1128 \cdot 7 \\
(100)\end{array}$ & $\begin{array}{c}1040 \cdot 1(121 \cdot 1)^{\star} \\
(92 \cdot 1)\end{array}$ & $\begin{array}{l}17.2(6.8)^{\star} \\
(1.5)\end{array}$ & $\begin{array}{l}11 \cdot 1(5 \cdot 1) \\
(1 \cdot 0)\end{array}$ & $\begin{array}{l}4.3(0.5) \\
(0.4)\end{array}$ & $\begin{array}{l}56 \cdot 0(7 \cdot 3)^{\star} \\
(5.0)\end{array}$ \\
\hline 1000 & $\begin{array}{l}1599 \cdot 1 \\
(100)\end{array}$ & $\begin{array}{l}1443.2(156.7)^{\star} \\
(90.3)\end{array}$ & $\begin{array}{l}36 \cdot 6(19 \cdot 2) \\
(2 \cdot 3)\end{array}$ & $\begin{array}{l}44 \cdot 6(8 \cdot 7) \\
(2 \cdot 8)\end{array}$ & $\begin{array}{l}9.3(1.4) \\
(0.6)\end{array}$ & $\begin{array}{l}65 \cdot 4(13 \cdot 8) \\
(4 \cdot 1)\end{array}$ \\
\hline 2000 & $\begin{array}{l}3441 \cdot 4 \\
(100)\end{array}$ & $\begin{array}{l}2914 \cdot 5(305 \cdot 1)^{\star} \\
(84 \cdot 7)\end{array}$ & $\begin{array}{c}118.3(49 \cdot 9)^{\star} \\
(3.4)\end{array}$ & $\begin{array}{l}275 \cdot 1(31 \cdot 4)^{\star} \\
(8.0)\end{array}$ & $\begin{array}{l}35 \cdot 2(16 \cdot 7) \\
(1.0)\end{array}$ & $\begin{array}{l}98.3(8 \cdot 6)^{\star} \\
(2 \cdot 9)\end{array}$ \\
\hline 4000 & $\begin{array}{l}5641 \cdot 6 \\
(100)\end{array}$ & $\begin{array}{l}4355 \cdot 0(735 \cdot 3)^{\star} \\
(77 \cdot 2)\end{array}$ & $\begin{array}{c}167.9(30 \cdot 2) \\
(3.0)\end{array}$ & $\begin{array}{l}907 \cdot 3(58 \cdot 7)^{\star} \\
(16 \cdot 1)\end{array}$ & $\begin{array}{l}67.4(14 \cdot 6)^{\star} \\
(1.2)\end{array}$ & $\begin{array}{l}144.0(22.6) \\
(2 \cdot 5)\end{array}$ \\
\hline \multicolumn{7}{|c|}{ PB group } \\
\hline 0 & $\begin{array}{l}37 \cdot 4 \\
(100)\end{array}$ & $\begin{array}{l}16 \cdot 5(1 \cdot 2) \\
(44 \cdot 2)\end{array}$ & $\begin{array}{l}1.9(1.0) \\
(5.0)\end{array}$ & ND & ND & $\begin{array}{l}19 \cdot 0(10 \cdot 7) \\
(50 \cdot 8)\end{array}$ \\
\hline 50 & $\begin{array}{l}200 \cdot 3 \\
(100)\end{array}$ & $\begin{array}{l}175.5(39.9) \\
(87.6)\end{array}$ & $\begin{array}{l}2.9(1.2) \\
(1.4)\end{array}$ & ND & $\begin{array}{l}1.4(0.2)^{\star} \\
(0.7)\end{array}$ & $\begin{array}{l}20 \cdot 5(9 \cdot 9) \\
(10 \cdot 2)\end{array}$ \\
\hline 100 & $\begin{array}{l}436 \cdot 3 \\
(100)\end{array}$ & $\begin{array}{l}405.8(55.3)^{\star} \\
(93.0)\end{array}$ & $\begin{array}{l}5 \cdot 1(2 \cdot 0) \\
(1 \cdot 2)\end{array}$ & ND & $\begin{array}{l}2.6(0.3)^{\star} \\
(0.6)\end{array}$ & $22 \cdot 8(14 \cdot 0)$ \\
\hline 250 & $\begin{array}{l}849 \cdot 0 \\
(100)\end{array}$ & $\begin{array}{l}795.9(117.5)^{\star} \\
(93.7)\end{array}$ & $\begin{array}{l}5 \cdot 8(3 \cdot 1) \\
(0 \cdot 7)\end{array}$ & ND & $\begin{array}{l}5.2(0.6) \\
(0.6)\end{array}$ & $\begin{array}{l}42 \cdot 1(3 \cdot 6) \\
(5 \cdot 0)\end{array}$ \\
\hline 500 & $\begin{array}{l}1477 \cdot 8 \\
(100)\end{array}$ & $\begin{array}{l}1322 \cdot 7(42 \cdot 0)^{\star} \\
(89 \cdot 5)\end{array}$ & $\begin{array}{l}20 \cdot 1(9 \cdot 0)^{\star} \\
(1 \cdot 4)\end{array}$ & $\begin{array}{l}66 \cdot 2(2.0) \\
(4.5)\end{array}$ & $\begin{array}{l}10.3(1.2)^{\star} \\
(0.7)\end{array}$ & $\begin{array}{l}58 \cdot 5(9 \cdot 1) \\
(4 \cdot 0)\end{array}$ \\
\hline 1000 & $\begin{array}{l}2750 \cdot 5 \\
(100)\end{array}$ & $\begin{array}{l}2353.8(192.6)^{\star} \\
(85.6)\end{array}$ & $\begin{array}{l}81.0(48.4)^{\star} \\
(2.9)\end{array}$ & $\begin{array}{c}213.3(34 \cdot 7) \\
(7 \cdot 8)\end{array}$ & $\begin{array}{l}24.5(7 \cdot 4)^{\star} \\
(0.9)\end{array}$ & $\begin{array}{l}77.9(6.3)^{\star} \\
(2.8)\end{array}$ \\
\hline 2000 & $\begin{array}{l}5224 \cdot 7 \\
(100)\end{array}$ & $\begin{array}{l}3430 \cdot 4(93 \cdot 2)^{\star} \\
(65.7)\end{array}$ & $\begin{array}{l}294.0(147.8)^{\star} \\
(5.6)\end{array}$ & $\begin{array}{l}1286.5(57.5)^{\star} \\
(24.6)\end{array}$ & $\begin{array}{l}77 \cdot 2(4 \cdot 7)^{\star} \\
(1.5)\end{array}$ & $\begin{array}{c}136 \cdot 6(5 \cdot 7)^{\star} \\
(2 \cdot 6)\end{array}$ \\
\hline 4000 & $\begin{array}{l}3481 \cdot 3 \\
(100)\end{array}$ & $\begin{array}{r}2232 \cdot 8 \\
(64 \cdot 1)\end{array}$ & $\begin{array}{l}48.5 \\
(1.4)\end{array}$ & $\begin{array}{l}957.6 \\
(27.5)\end{array}$ & $\begin{array}{l}89.9 \\
(2.6)\end{array}$ & $\begin{array}{c}152.5 \\
(4.4)\end{array}$ \\
\hline
\end{tabular}

The numbers ( $\mu \mathrm{mol} / \mathrm{kg}$ ) represent the mean (SD) in five rats except for that of $4000 \mathrm{ppm}$ exposure in PB group, where the mean for two rats is presented. Other values in parentheses are percentages of total metabolites.

HA = Hippuric acid; F-BA = free benzoic acid; BG = benzoyl glucuronide.

$\star$ Significantly different from that of respective control group $(p<0.05) ; \mathrm{ND}=$ not detected.

Ethanol treatment increased the amount of HA, but did not express so much influence on the percentage of HA in total metabolites, with the exception of the two highest exposures (2000 and $4000 \mathrm{ppm}$ ) where the percentage decreased to $84 \cdot 7$ and $77 \cdot 2 \%$ with a simultaneous increase in the percentage of BG to 8.0 and $16.1 \%$ respectively. The percentage of $p$ cresol was not apparently influenced by ethanol treatment, although the amount of this metabolite increased significantly at all exposures except to 1000 and $4000 \mathrm{ppm}$. The cumulative $o$-cresol excretion was not affected by ethanol treatment except at exposures to 50 and $4000 \mathrm{ppm}$ toluene.

Phenobarbital had a similar effect on the cumulative excretion of HA, F-BA, and BG. It increased the percentage of $B G$ to as high as 24.6 and $27.5 \%$ at 2000 and $4000 \mathrm{ppm}$ exposure respectively. By comparison with ethanol treatment, $P B$ increased the cumulative amount of $o$-cresol significantly at almost all exposures and $p$-cresol excretion only at high toluene exposures. As in untreated rats, the excreted amount of $p$-cresol in 24 hours showed no 
Table 2 The kinetic constants in vivo for urinary metabolites of toluene during six hour exposure

\begin{tabular}{|c|c|c|c|c|c|c|}
\hline \multirow[b]{2}{*}{ Treatment } & \multicolumn{2}{|c|}{$H A+F-B A+B G$} & \multicolumn{2}{|c|}{ o-Cresol } & \multicolumn{2}{|c|}{ p-Cresol } \\
\hline & $K_{m}$ & $V_{\max }$ & $K_{m}$ & $V_{\max }$ & $\boldsymbol{K}_{m}$ & $V_{\max }$ \\
\hline Control & $\begin{array}{l}182 \\
600\end{array}$ & $\begin{array}{l}394 \\
664\end{array}$ & 407 & 6 & 86 & 15 \\
\hline $\begin{array}{l}\text { Ethanol } \\
\text { PB }\end{array}$ & $\begin{array}{r}522 \\
882 \\
1634\end{array}$ & $\begin{array}{l}1291 \\
1342 \\
3453\end{array}$ & $\begin{array}{r}414 \\
1622\end{array}$ & $\begin{array}{r}8 \\
30\end{array}$ & $\begin{array}{l}122 \\
431 \\
729\end{array}$ & $\begin{array}{l}29 \\
43 \\
62\end{array}$ \\
\hline
\end{tabular}

*Values represent the mean determined from five rats.

HA = Hippuric acid; F-BA = free benzoic acid; $B G=$ benzoyl glucuronide; $K_{m}=$ Michaelis constant $(p p m) ; V_{\max }=$ maximal velocity $(\mu \mathrm{mol} / \mathbf{k g})$.

significant increase at low exposure concentrations (until $250 \mathrm{ppm}$ ).

\section{Kinetics of toluene metabolism}

Table 2 lists the Michaelis constants $\left(K_{m}\right)$ (the concentration of toluene exposure at which excretion proceeds at half maximal velocity) and maximal velocities $\left(\mathrm{V}_{\max }\right)$ (the maximum rate of metabolite excretion in urine during a six hour exposure), calculated using the least squares method. Three urinary metabolites, HA, F-BA and BG, were summed as one route of metabolism because they originated from the same intermediate of toluene, benzoic acid. For this side chain hydroxylation, two isozymes were calculated for control and ethanol treated groups. In the control group one had a low $\mathrm{K}_{\mathrm{m}}$ (182 $\mathrm{ppm})$, and the other a high $\mathrm{K}_{\mathrm{m}}(600 \mathrm{ppm})$. In ethanol treated rats the $K_{m}$ values for both isozymes were larger (522 and $882 \mathrm{ppm}$ respectively) with higher $V_{\max }$ values. Only one enzyme was detected for the side chain hydroxylation in PB treated rats, and this had much greater $K_{m}$ and $V_{\max }$ values.

Only one enzyme was detected for $o$-cresol $\left(\mathrm{K}_{\mathrm{m}}\right.$, $407 \mathrm{ppm}$ ) in control rats, with a small $V_{\max }$ value. Ethanol treatment seemed to have little effect on this enzyme $\left(K_{m}, 414 \mathrm{ppm}\right)$. In PB treated rats, the enzyme involved in o-cresol metabolism showed a much larger $\mathrm{K}_{\mathrm{m}}$, and the $\mathrm{V}_{\max }$ was also increased.

One enzyme was detected for $p$-cresol in control rats, with smaller $K_{m}(85 \mathrm{ppm})$ and $V_{\max }(15 \mu \mathrm{mol} / \mathrm{kg})$ in comparison with that of side chain metabolism. Ethanol treatment increased the $V_{\max }$ value by about 2.5 times, and furthermore, one more isozyme with a larger $K_{m}$ value ( $515 \mathrm{ppm}$ ) was detected in this group at high toluene concentrations. In PB treated rats, there was one enzyme for $p$-cresol with a larger $K_{m}$ $(728 \mathrm{ppm})$ than that of the high $\mathrm{K}_{\mathrm{m}}$ type in the ethanol group, indicating that PB may express an effect on $p$ cresol metabolism only at high toluene concentrations.

\section{Discussion}

Benzyl alcohol is the most essential metabolite in in vitro toluene metabolism. ${ }^{45}$ Most of this intermediate is transformed to benzoic acid and excreted in urine as $\mathrm{HA}$ after conjugation with glycine in vivo. ${ }^{11}{ }^{12}$ This was confirmed in the present experiment with a wide range of exposure concentrations of toluene.

The enzyme that metabolises toluene at its side chain to benzyl alcohol and eventually to benzoic acid has been confirmed in previous experiments to be cytochrome P-450. ${ }^{45}$ The activity of this enzyme is intimately correlated with the excreted amounts of metabolites from side chain transformation. Ethanol and PB treatment in the present study, for example, greatly influenced the amount of HA, F-BA, and BG in urine through the enhancement of isozyme activity. Therefore, it could be said that the transformation of toluene to benzyl alcohol catalysed by cytochrome P-450 is the rate limiting step in the side chain metabolism of toluene.

In the present study, with wide toluene concentrations, an increase in benzoic acid after $\beta$-glucuronidase treatment of a urine sample was found when the exposure concentration of toluene was raised to 2000 ppm in control rats. This result gives indirect supporting evidence that benzoic acid could conjugate with glucuronic acid, as well as glycine, to form a separate metabolite from $\mathrm{HA}$ at higher exposures to toluene. Quistad et al ${ }^{13}$ recently reported that a small amount of benzoylcarnitine was detected in the urine of rats dosed with ${ }^{14} \mathrm{C}$ benzoic acid. Whether the conjugate of benzoic acid with carnitine is included in the urinary metabolites, has to be confirmed.

We noted that BG could be detected when the cumulative amount of F-BA during six hours of exposure was more than $5 \mu \mathrm{mol} / \mathrm{kg}$ in all the three groups. Fishbein ${ }^{14}$ and Riihimäki ${ }^{15}$ suggested that conjugation of benzoic acid with glucuronic acid occurs when glycine conjugation is saturated. We think that this conjugating reaction with glucuronic acid depends on the amounts of benzoic acid accumulated and the glycine conjugation reaction is not saturated. In agreement with this view excretion of HA still increased with toluene exposure concentration when BG was detected in urine. This may indicate the existence of an enzyme with a much larger $K_{m}$ value mediated in the glucuronic acid 
conjugating reaction, compared with the $K_{m}$ value of glycine conjugating enzyme. The conjugating reaction of benzoic acid with glucuronic acid may be another step to limit the side chain metabolism of toluene, especially at high toluene concentrations.

The amount of F-BA in urine increased with the increase in toluene concentration, so F-BA could be thought of as another metabolite of toluene, although its amount was minute compared with HA.

Treatment with ethanol enhanced the excretion of HA, as reported elsewhere. ${ }^{16}$ At low toluene concentration-for example, $250 \mathrm{ppm}$ - the amount of HA in urine during six hours of exposure was increased more than twofold by ethanol, whereas at high exposure-for example, $2000 \mathrm{ppm}$ - it increased only 1.5-fold. Ethanol treatment had little effect on $V_{\max }$ and $\mathrm{K}_{\mathrm{m}}$ of isozyme for $o$-cresol. At toluene exposures up to $1000 \mathrm{ppm}$, urinary $o$-cresol was not increased by ethanol treatment. At high toluene concentrations, the amount of $o$-cresol excreted in six hour urine was significantly increased in the ethanol group, but the amount in 24 hour urine was not increased except at $4000 \mathrm{ppm}$. Ethanol increased p-cresol excretion. From the result of blood determinations, it was found that ethanol treatment increased toluene clearance from blood only when the concentration in blood was not high. These results indicate that treatment with ethanol enhances the side chain hydroxylation of toluene, especially at low toluene concentrations; increases ring oxidation at the $p$ position; and has little effect on $o$-cresol metabolism.

Phenobarbital treatment induced an isozyme for side chain metabolism with large $K_{m}$ and $V_{\max }$ values. It significantly increased HA excretion. For $o$-cresol metabolism, PB treatment also expressed a significant promoting effect at all exposure concentrations. For ring metabolism at the $p$ position, it showed an effect only at high toluene concentration. These results were in agreement with in vitro experiments. ${ }^{4}$

A variety of chemicals including organic solvents have been reported to be subject to perfusion limited metabolism at low exposure concentrations ${ }^{17}$ (the metabolism rate is controlled by blood flow to the liver, and not influenced by enzyme induction). In this study, even after exposure to low toluene concentrations, the excretion of HA and F-BA, and $o-$ cresol in six hour urine was significantly increased by ethanol and PB treatments (fig 3A, B, D), although the two treatments did not promote toluene clearance from blood below 250 ppm exposure (fig 1). This suggests that the metabolism of toluene is perfusion limited only at very low exposure concentrations.

Sato and Nakajima ${ }^{18}$ reported that $\mathrm{PB}$ treatment increases the activity of UDP-glucuronyltransferase in rat liver, and ethanol treatment also increased the activity of the enzyme although the difference was not significant. Yost and Finley ${ }^{19}$ found a significant induction of UDP-glucuronyltransferase activity by ethanol in rabbits. In this study, the excretion of BG was promoted in both ethanol and PB treated rats. This may be explained with increase in the production of benzoic acid, which is one of the substances of the enzyme and the increased activity of UDPglucuronyltransferase involved in the conjugation of benzoic acid with glucuronic acid.

The excretion of $p$-cresol in urine did not show an increase with increasing exposure concentration when toluene concentration was low (50 and 100 ppm) in the three groups (table 1). We investigated the cause in vitro with liver microsomes of rats. It has been found that $p$-cresol was cleared from the reaction system by the microsome mediated metabolism, and a new peak was detected in the HPLC chromatogram (data not shown). This phenomenon was more significant with microsomes from ethanol and $P B$ treated rats. $A$ similar finding was observed in urine samples of rats. This means that $p$-cresol is not the end metabolite. The available five isomers of dihydroxytoluene (DHT: 2,3-DHT, 2,5-DHT, 2,6DHT, 3,4-DHT, and 3,5-DHT) were used in an attempt to identify the substance but it was not any of these isomers. The identification of the new metabolite is therefore to be further undertaken.

With monoclonal antibodies to different types of cytochrome $\mathbf{P}-450$, we found that cytochromes $\mathrm{P}-450$ IIE 1 and $\mathrm{P}-450$ IIC $11^{20}$ are mainly responsible for the formation of BA and p-cresol at high- and low affinity sites of toluene respectively. ${ }^{5}$ Cytochrome $\mathrm{P}-450 I I E 1$ is also an ethanol inducible enzyme. ${ }^{21} \mathrm{~PB}$ inducible P-450IIB contributes to the formation of the three metabolites. The low $K_{m}$ isozyme for side chain metabolism in this experiment in control and ethanol treated rats may be $\mathrm{P}-450 \mathrm{IIE} 1$, although the $K_{m}$ value in the ethanol group is larger. The high $K_{m}$ isozymes in the two groups may reflect P-450IIC11, which is also the constructive cytochrome $\mathrm{P}-450$ in microsomes as P-450IIE1 and which acts mainly at high toluene concentrations. Similarly, the low (86122) and high (431) $K_{m}$ isozymes in $p$-cresol formation may be cytochrome P-450IIE 1 and P-450IIC11 respectively. The isozyme responsible for $o$-cresol formation in control and ethanol treated rats is not identified yet. The PB induced enzyme that acts in the metabolism of the side chain and in the formation of $o$ - and $p$-cresol is cytochrome P-450IIB.

Three of the five rats died at exposure to $4000 \mathrm{ppm}$ toluene in the PB group. With PB treatment, the clearance of the solvent was significantly enhanced (fig 1) suggesting that it is a metabolite of toluene that mediates the toxicity. At this exposure, the most remarkable occurrence was a significant decrease in the excretion of side chain metabolites compared with that at exposure to $2000 \mathrm{ppm}$ and this excretion was even less than that of ethanol treated rats. These results may indicate the accumulation of acidic side chain metabolites. Exposure to a high concentration 
of toluene has been reported to lead to metabolic acidosis. ${ }^{22}$ It seems that the death of rats in our present study may be related to life threatening metabolic acidosis as a result of high concentration of acids such as HA and F-BA in PB treated rats. The mechanism whereby acidosis may be caused and how renal function is involved, requires further study.

Hippuric acid has been used in the biological monitoring of people exposed to toluene. ${ }^{23}$ The physiological presence of HA in the urine of nonexposed subjects originating from food, drugs etc reduces its importance as an index of biological monitoring, especially at low exposure. ${ }^{24}$ Some investigators have attempted to use $o$-cresol as the monitoring index. ${ }^{12}$ In this experiment, $o$-cresol showed a relatively specific, constant small amount of excretion in urine $(0.5-1.1 \%$ of total metabolites), and was hardly influenced by ethanol. On the other hand, HA corresponded to $92 \%$ of total metabolites even at low exposure to toluene. The correlation coefficient between HA in six hour urine and toluene concentration (0.90) was not inferior to that between $o$-cresol and toluene concentration $(0.89)$. Studies in human subjects showed that the coefficient between $\mathrm{HA}$ and toluene was larger than that between $o$-cresol and toluene concentration. ${ }^{1125}$ Taking these advantages of HA into consideration, it could be suggested that HA is still a valuable index of biological monitoring of exposure to toluene, and it may be more reasonable to determine HA and free benzoic acid in urine than HA only, at low exposure.

We thank Professor Ninzo Murayama for his generous support and helpful comments. This work was supported in part by a research grant (No 02807059) from the Japan Ministry of Education, Science and Culture.

Requests for reprints to: Dr T Nakajima, Department of Hygiene, Shinshu University School of Medicine, Matsumoto 390, Japan.

1 US Environmental Protection Agency. Toluene. Rev Environ Contam Toxicol 1988;106:189-201.

2 Guzeliam P, Miller S, Fallon HJ. Liver structure and function in print workers exposed to toluene. JOccup Med 1988;30:791-6.

3 Hsieh G, Sharma R, Parker RD. Immunotoxicological evaluation of toluene exposure via drinking water in mice. Environ Res 1989;49:93-103.

4 Wang RS, Nakajima T. Kinetic studies on toluene metabolism in ethanol- and phenobarbital-induced rat liver microsomes in vitro. Arch Toxicol 1991;65:39-44.
5 Nakajima T, Wang RS, Elovaara E, et al. Monoclonal antibodydirected characterization on cytochrome $\mathbf{P 4 5 0}$ isozymes responsible for toluene metabolism in rat liver. Biochem Pharmacol 1991;41:395-404.

6 DeCarli LM, Lieber CS. Fatty liver in the rat after prolonged intake of ethanol with a nutritionally adequate liquid diet. $J$ Nutr 1967;91:331-6.

7 Nakajima T, Okino T, Okuyama S, Kaneko T, Yonekura I, Sato A. Ethanol-induced enhancement of trichloroethylene metabolism and hepatotoxicity: difference from the effect of phenobarbital. Toxicol Appl Pharmacol 1988;94:227-37.

8 Sato A, Nakajima T, Fujiwara Y, Murayama N. A pharmacokinetic model to study the excretion of trichloroethylene and its metabolites after an inhalation exposure. $\mathrm{Br} J$ Ind $\mathrm{Med}$ 1977;34:56-63.

9 Sato A, Nakajima T, Fujiwara Y. Determination of benzene and toluene in blood by means of a syringe-equilibration method using a small amount of blood. Br J Ind Med 1975;32:210-14.

10 Takeuchi Y, Sakai T, Ikeya T, Araki T, Ushio K, Yanagihara S. Improved high performance liquid chromatograph determination of hippuric acid and methylhippuric acid isomers in urine. Japanese Journal of Industrial Health 1986;28:455-61. (In Japanese with an English summary.)

11 DeRosa E, Brugnone F, Bartolucci GB, et al. The validity of urinary metabolites as indicators of low exposures to toluene. Int Arch Occup Environ Health 1985;56:135-45.

12 Døssing M, Aelun JB, Hansen SH, Lundqvist GR, Anderssen NT. Urinary hippuric acid and orthocresol excretion in man during experimental exposure to toluene. $\mathrm{Br} J$ Ind $\mathrm{Med}$ 1983;40:470-3.

13 Quistad GB, Staiger LE, Schooley D. The role of carnitine in the conjugation of acid xenobiotics. Drug Metab Dispos 1986;14:521-5.

14 Fishbein L. An overview of environmental and toxicological aspects of aromatic hydrocarbons. II. Toluene. Sci Total Environ 1985;42:267-88.

15 Riihimäki V. Conjugation and urinary excretion of toluene and $m$-xylene metabolites in man. Scand $J$ Work Environ Health 1979;5:135-42.

16 Sato A, Nakajima T, Koyama Y. Effects of chronic ethanol consumption on hepatic metabolism of aromatic and chlorinated hydrocarbons in rats. $B r J$ Ind Med 1980;37:382-6.

17 Andersen ME. Physiologically based toxicokinetic description of the metabolism of inhaled gases and vapors: analysis at steady state. Toxicol Appl Pharmacol 1981;60:509-26.

18 Sato A, Nakajima T. Enhanced metabolism of volatile hydrocarbons in rat liver following food deprivation, restricted carbohydrate intake, and administration of ethanol, phenobarbital, polychlorinated biphenyl and 3-methylcholanthrene: a comparative study. Xenobiotica 1985;15:67-75.

19 Yost GS, Finley BL. Ethanol as an inducer of UDP-glucuronyltransferase: a comparison with phenobarbital and 3-methylcholanthrene induction in rabbit microsomes. Biochem Biophys Res Commun 1983;111:219-23.

20 Nebert DN, Nelson DR, Adesnik M, et al. The P450 superfamily: Updated listing of all genes and recommended nomenclature for the chromosomal loci. $D N A$ 1989;8:1-13.

21 Ko IY, Park SS, Song BJ, et al. Monoclonal antibodies to ethanol-induced rat liver cytochrome $\mathrm{P}-\mathbf{4 5 0}$ that metabolizes aniline and nitrosamines. Cancer Res 1987;47:3101-9.

22 Fischman CM, Oster JR. Toxic effects of toluene: a new cause of high anion gap metabolic acidosis. JAMA 1979;241:1713-5.

23 Pagnotto LD, Lieberman LM. Urinary hippuric acid excretion as an index of toluene exposure. Am Ind Hyg Assoc J 1967;28:129-34

24 Andersson R, Carlsson A, Nordqvist MB, Sollenberg J. Urinary excretion of hippuric acid and $o$-cresol after laboratory exposure of humans to toluene. Int Arch Occup Environ Health 1983;53:101-8.

25 Hasegawa K, Shiojima S, Koizumi A, Ikeda M. Hippuric acid and $o$-cresol in the urine of workers exposed to toluene. Int Arch Occup Environ Health 1983;52:1979-208.

Accepted 10 June 1991 